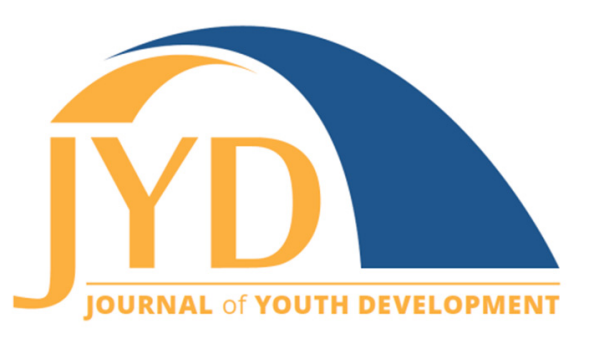

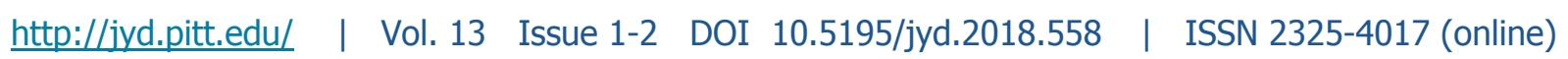

\title{
Camp and College Parallels: Crucibles for Transition-Linked Turning-Points
}

\author{
Lisa K.-P. Olsen \\ Clemson University \\ Ikolsen@clemson.edu
}

Gwynn M. Powell

Clemson University

gwynnp@clemson.edu

Barry A. Garst

Clemson University

bgarst@clemson.edu

Robert D. Bixler

Clemson University

rbixler@clemson.edu

\section{Abstract}

This conceptual paper explores how the system of experiences that children encounter in a traditional, residential summer camp setting parallel traditional, residential, college setting for first-year students. Camp is a complex system in the sphere of youth development programs (YDP) because of the expectation for rapid adjustment by the camper to a novel physical and social environment. Many YDPs have a moderate to high level of connection with the child's normal life, defined as similar to school or home environments and the activities in which youth regularly participate. A traditional residential summer camp offers a different degree of novelty than most other YDP settings. This paper offers a list of physical elements present in a camp setting that parallel the college setting and considers common camp-college parallels to articulate connected physical, social, emotional, and intellectual domains. This integration of ideas illustrates how the socio-physical novelty of the camp experience serves as a crucible for rapid adjustment and multi-dimensional growth in a way that is uniquely different from many other youth development settings.

Key words: physical setting, camp, college, turning-points, transitions

(cc) EY New articles in this journal are licensed under a Creative Commons Attribution 4.0 License. This journal is published by the University Library System, University of Pittsburgh and is cosponsored by the University of Pittsburgh Press. The Journal of Youth Development is the official peer-reviewed publication of the National Association of Extension 4-H Agents and the National AfterSchool Association. 
Camp and College Parallels

\section{Camp as a Developmental Crucible}

In many ways, the process of going away to a traditional residential summer camp is a child's version of going off to a traditional college setting. This conceptual paper explores how the complex system of experiences children encounter in a traditional, residential summer camp setting parallels traditional, residential first-year college students' experiences. By drawing parallels between youth experiences in summer camp and college settings, this paper describes the interior of the "black box" of residential summer camps that has been described primarily with discrete psychological constructs representing mostly inputs and outputs of the camp experience. As a field, the outcomes of camp participation are well documented, but we have less clarity about what actually happens to the camper during the experience. The label "black box" was coined to explain the less transparent process between inputs and outputs. We argue that camp is a complex system, a unique context in the sphere of youth development programs (YDPs) because of the expectation for rapid adjustment by the camper to a novel physical and social environment. This adjustment to camp, as a new context, catalyzes development in a parallel fashion to the expectation for first-year undergraduate students to 'grow up' at college.

Previous residential summer camp research documents normatively desirable outcomes typical of those found in the youth development literature but often fails to distinguish summer camps from other YDPs and settings. For instance, Garst and Gagnon (2016) found that summer camps provided parental-observed growth in their campers in responsibility, self-regulation, exploration, communication and attitude. Henderson, Whitaker, Bialeschki, Scanlin, and Thurber (2007) described parents perceiving their child as having increases in abilities across 10 constructs commonly measured in youth development research. These findings are not unique, as many other YDPs have demonstrated comparable outcomes. Furthermore, when considered apart from the setting, none of these outcomes by themselves differentiate summer camps from other YDPs.

A traditional residential camp is not an everyday experience. While many YDPs have a moderate to high level of connection with the child's normal life, defined as being similar to school or home environments and the activities in which youth regularly participate, residential summer camp offers a higher degree of novelty than most other settings. Within the context of most YDPs, a young person can recognize something s/he would perceive as normal, whether it be the neighborhood ball field, the adult leader known through the school, the activities and games, or simply the feelings of comfort, safety, belonging, and connectedness that often accompany familiar milieu. In contrast, residential summer camp involves removing the child 
Camp and College Parallels

from a familiar setting and placing him or her into a novel physical place and social setting with intentional support designed to help the child navigate the disruption of the typical day-to-day experience and successfully integrate into the camp environment. We argue that a successful camp experience may serve as an important transition-linked turning-point that sets a child up for additional success when faced with the similar disruption of "normal" when he or she goes away to college.

\section{Rapid Adaptation and Learning}

The physical setting of a traditional residential summer camp is structured in such a way as to require rapid adaptation and learning from the newly arrived camper. We argue that residential camps are complex (Funnell \& Rogers, 2011) because settings associated with residential camp are a precursor to generating experiences that lead to positive youth development outcomes. While camps provide food, shelter and safety in much the same way that a child's family and community do, the distance from home, the extent or vastness of the camp property, a more natural setting, and the communal group facilities immerses the camper in a moderately novel setting. A limited number of studies address the relationship of summer camp and college. Scheder (2016) asked current first- and second-year college students to reflect on their lived experiences as youth to learn what influenced their transition to college life. When camp was mentioned, Scheder probed to learn more, and documented that students perceived the intrapersonal and interpersonal skills they developed at camp transferred to their new collegesetting and supported their adjustment to college. Two somewhat related studies addressed university campus-based "camps" for pre-collegiate youth specifically designed to prepare students for college in areas such as taking the ACTs (Bourdeau, Galloway, Arnold, \& Nott, 2014) or learning about scholarships and options for college (Kirk \& Day, 2011).

Although limited research exists related to the camp-college connection, numerous testimonials in popular media attribute success in college to residential camp experiences, mostly from college students. Schwartz (2015) wrote about how summer camp prepared her for college by listing 15 reasons, which included learnings such as ease of living with a college roommate after having lived with 14 girls at summer camp, functioning on minimal sleep, and being less likely to make bad decisions because she had already experienced some independence. Likewise, as a rising first-year college student, Baskin (2016a) recalled questions many new college students ponder: "Can I survive the new level of academia? What about the changing social environment? Roommates? Parent separation? What about a sense of identity?" (para. 1), and claimed, "The answers to all those questions I've found in summer camp" (para. 2). Sims 
(2015) expressed that going to camp provided her the ability to be open-minded when meeting new people, which is "crucial as a freshman in college" (para. 4). She referenced generic steps toward independence that camp taught her, such as showering and brushing her teeth, but most of all camp taught her how to "leave home and create my own experiences" (Sims, 2015., para. 6).

\section{Transition-Linked Turning-Points}

When a young person enters the residential camp setting, he or she enters a simultaneously novel social, physical, and activity-based setting, which creates one or more turning-points that may lead to transitions. Turning-points are times in a person's life when behavior, context, and cognition change, resulting in a robust lifestyle change (Pickles \& Rutter, 1991). Rutter (1996) argued that a turning-point must include a specific event that changes a person's circumstance and has a direct effect on the person's life (Enz \& Talarico, 2015). However, people may not recognize at the time the impact the event had (Clausen, 1995). Graber and Brooks-Gunn (1996) argued that in order for one to really have a turning-point, it must be linked to transitions, also known as a transition-linked turning-point.

Transitions do not depend on one single event, but rather are viewed as an experience signifying a rite of passage (Enz \& Talarico, 2015). For instance, when students graduate from high school they are normatively considered adults. Transitions occur due to a variety of social, biological, and psychological phenomena (Graber \& Brooks-Gunn, 1996). Biological examples include puberty or a physical injury, while others are social or emotional due to deepening relationships with other people (Brown, Hanson, Lee, Vanderveen, \& Conrad, 2012). During transition periods, it is fortuitous for a person to reorganize the daily functions, such as structural and functional events, like puberty, that lead into adolescence and eventually adulthood (Kagan, 1984; Rutter, 1996, \& Graber \& Brooks-Gunn, 1996). When turning-points are a result of a specific event, a transition generally occurs. For example, a parent's perception that their child is mature enough to go away to camp embraces both turning-points and the possibility of transitions. Camp dramatically alters the social lifestyle of the child.

Going to college is a common turning-point and transition. Like camp, it involves leaving home and immersing oneself in a novel socio-physical environment with different norms. These changes require rapid adaptations by the person. Not surprisingly, when someone is asked about noteworthy times during their life, turning-points and transitions commonly come to mind (Enz \& Talarico, 2015). 


\section{Novel Physical Places as the Crucible for Development}

The physical aspects of residential summer camps create socio-physical settings that require rapid adjustments and learning. Many of these physical, structural characteristics are also present in and around college campuses. Within a matter of an hour or two of travel, a camper is living in a new setting, unable to easily return home, and knows little of the layout of the new place. The setting is large enough that some or most destinations are out of sight of each other, requiring increasingly complex wayfinding decisions. The natural setting is complex, creating a display of thousands of living and nonliving objects, many previously unknown. Darkness arrives just like at home, but lighting is different and often limited. Particularly at night, unknown sounds stimulate the imagination, initially creating anxiety. The privacy and modesty of the family home is exchanged for small to large group living and dining arrangements (Bixler \& James, 2016; Kaplan, Kaplan, \& Ryan, 1998). These same characteristics, to a greater or lesser extent, are often found in the adjustment to the physical aspects of a traditional college campus. While many YDPs provide youth with exposure to similar social elements, the adjustment to the combination of physical and social novelty within summer camp settings catalyzes the desired positive youth development outcomes that are the goal of most developmental systems (Gambone \& Connell, 2004) and ecological models (Derksen, 2010). Table 1 shows parallels between physical setting characteristics of camp and college.

In addition to the parallels between the physical settings of camps and college campuses, there are similarities in the functionality of both settings. The layout of the buildings requires one to develop wayfinding skills and basic survey knowledge of specific locations, learn routes from place to place. The layout may also introduce complexity that motivates novel travel-path decisions. Both camp and campus settings are structured to service and manage small and large groups of people. Buildings at camp and on campus parallel the home environment in their provision of common and essential services such as food, shelter, learning, entertainment and worship. The functionality of spaces is well defined. Exterior space is designed to facilitate walking and limit motorized transportation. Camps and Campuses are both often geographically distant from family and home community, and are sometimes even isolated. 
Camp and College Parallels

Table 1. Parallels between Camp and College Setting Characteristics

\begin{tabular}{l|l}
$\begin{array}{l}\text { The physical setting of traditional camp } \\
\begin{array}{l}\text { Varying lighting conditions and patterns require } \\
\text { new skills and confidence to negotiate indoor } \\
\text { and outdoor spaces }\end{array}\end{array}$ & $\begin{array}{l}\text { Less control of lighting patterns and the need to } \\
\text { develop judgment about areas that are safe at } \\
\text { different times of day and night }\end{array}$ \\
\hline $\begin{array}{l}\text { Exposure to unfamiliar (predominantly natural } \\
\text { flora and fauna) sounds }\end{array}$ & $\begin{array}{l}\text { Exposure to unfamiliar (predominantly human) } \\
\text { sounds }\end{array}$ \\
\hline $\begin{array}{l}\text { Novel and often rustic architecture } \\
\text { Complex and dynamic visual array of natural } \\
\text { objects }\end{array}$ & Novel and often historic architecture \\
\hline $\begin{array}{l}\text { The setting defines the experience. Programs } \\
\text { are created around unique physical features of } \\
\text { the property (lakes, rivers, meadows, } \\
\text { mountains, etc.) }\end{array}$ & $\begin{array}{l}\text { The setting evokes a feel that is different from } \\
\text { campus to campus }\end{array}$ \\
\hline
\end{tabular}

\section{Youth Developmental Outcome Parallels Between Camp and College}

While traditional residential summer camps vary in philosophy, staffing, landscape, facilities, and daily activities, camps provide settings and experiences that parallel a first semester college experience. Adapting physically, socially, emotionally, and intellectually both at camp and college mirror the pillars of effective YDPs (National Research Council (NRC), 2002). The next section explores each of these four developmental pillars. A detailed list, informed by professional experiences of the authors, conversations with former campers, and existing research from several fields serves as a basis for intentionally examining common features of many traditional resident camp experiences alongside parallel features of going away to college. These features are paired with the outcome that might be experienced by the camper or firstyear college student as a result of their camp or college encounter. We argue that the complex, novel socio-physical settings of both camp and college create the situations where people more naturally cooperate and rely on each other. This interdependence contributes to achievement of the desired outcomes. 


\section{Physical Development Parallels}

For camps, physical development refers to youths' physical growth and dexterity that results in safe and efficient navigation in a novel and aesthetic setting. The adaptations include less people-controlled environmental conditions as well as the exposure to new physical activities (NRC, 2012). At a residential summer camp the landscape is unique and complex and often includes living space, dining center, health care center, and activity locations. The terrain is often rough or more primitive compared to a suburban or urban setting; trips and falls are common particularly during the first few days of camp (Garst, Erceg, \& Walton, 2011). Campers must learn spatial relationships and reasoning, particularly in terms of wayfinding (Bixler and James, 2016). By navigating from one location to another on their own, campers create mental maps based first on route knowledge. Over a period of a few days, they develop more complex survey knowledge that allows them to derive novel routes around camp (Kaplan, et al., 1998). Similarly, new college students must quickly learn to navigate the campus property, which can include, dining halls, residence halls, recreation facilities, classrooms, libraries, and off-campus locations for food, entertainment and services. Table 2 describes additional physical elements of camp that have parallels with college along with their resulting outcomes.

While campers and college students may have participated in hometown clubs or sports while growing up, camp and college often provide unfamiliar experiences. For example, a typical camper does not have a ropes course in their backyard or twenty other friends to collaborate with on a dramatic performance. Likewise, a first-time college student is not accustomed to accessing multiple club and activity opportunities all within the same day, week, or month. These novel experiences set the stage for the growth of new skills, increases in body spatial awareness, and physical development. As these physical development experiences in both camp and college are often shared with others, they naturally spill over into opportunities for social development. 
Camp and College Parallels

Table 2. Physical Development Parallels between Camp and College

\begin{tabular}{|l|l|l|l|}
\hline Camp provides & College provides & $\begin{array}{l}\text { Camper } \\
\text { experiences }\end{array}$ & $\begin{array}{l}\text { First-year student } \\
\text { experiences }\end{array}$ \\
\hline $\begin{array}{l}\text { Camp property with } \\
\text { multiple buildings }\end{array}$ & $\begin{array}{l}\text { Campus with } \\
\text { multiple buildings }\end{array}$ & $\begin{array}{l}\text { Figured out where } \\
\text { things are with staff- } \\
\text { guidance }\end{array}$ & $\begin{array}{l}\text { Figured out where } \\
\text { things are on my own } \\
\text { with a map or app }\end{array}$ \\
\hline $\begin{array}{l}\text { Screened windows with } \\
\text { exposure to elements } \\
\text { of heat, rain, cool }\end{array}$ & $\begin{array}{l}\text { Less individual } \\
\text { control of } \\
\text { temperatures }\end{array}$ & $\begin{array}{l}\text { Learned to adapt to } \\
\text { different weather } \\
\text { conditions }\end{array}$ & $\begin{array}{l}\text { Learned to adapt } \\
\text { when no control of } \\
\text { thermostat }\end{array}$ \\
\hline $\begin{array}{l}\text { Uneven natural walking } \\
\text { paths with rocks, roots, } \\
\text { and other natural } \\
\text { features }\end{array}$ & Walking paths & Walked without tripping \\
\hline $\begin{array}{l}\text { Rest time } \\
\text { Primary navigation by foot or bicycle (as } \\
\text { opposed to motorized travel) }\end{array}$ & $\begin{array}{l}\text { Schedule flexibility } \\
\text { for naps, if desired }\end{array}$ & $\begin{array}{l}\text { Recharged by slowing down my body and } \\
\text { brain }\end{array}$ \\
\hline Became stronger because of the walk/ride to \\
most places
\end{tabular}

\section{Social Development Parallels}

Social development provides adolescents with connectedness to peers and a sense of place to feel valued by a larger social group (NRC, 2002). Table 3 describes social elements of camp that have parallels with college along with their resulting outcomes. 
Camp and College Parallels

Table 3. Social Development Parallels between Camp and College

\begin{tabular}{|c|c|c|c|}
\hline Camp provides & College provides & $\begin{array}{l}\text { Camper } \\
\text { experiences }\end{array}$ & $\begin{array}{l}\text { First-year student } \\
\text { experiences }\end{array}$ \\
\hline $\begin{array}{l}\text { Cabin with multiple } \\
\text { children }\end{array}$ & $\begin{array}{l}\text { Residence hall with } \\
\text { multiple students }\end{array}$ & \multicolumn{2}{|c|}{$\begin{array}{l}\text { Learned to share space. Kept things tidy. } \\
\text { Had to adjust to others' sleeping styles (e.g., } \\
\text { early risers, snorers) }\end{array}$} \\
\hline Bunkbeds in cabins & $\begin{array}{l}\text { Residence hall with } \\
\text { bunkbeds or lofts }\end{array}$ & $\begin{array}{l}\text { Slept close to a } \\
\text { cabin mate }\end{array}$ & $\begin{array}{l}\text { Slept in close quarters } \\
\text { with a roommate }\end{array}$ \\
\hline \multicolumn{2}{|c|}{ Small talk with strangers } & \multicolumn{2}{|c|}{ Practiced talking to strangers } \\
\hline \multicolumn{2}{|c|}{$\begin{array}{l}\text { New social milieu to layer onto existing } \\
\text { social-circles }\end{array}$} & \multicolumn{2}{|c|}{$\begin{array}{l}\text { Learned to balance different sets of friends } \\
\text { (i.e., "home" and "camp" friends) }\end{array}$} \\
\hline \multicolumn{2}{|c|}{$\begin{array}{l}\text { A place to interact with people of various } \\
\text { ages }\end{array}$} & \multicolumn{2}{|c|}{$\begin{array}{l}\text { Made friends with people that were older } \\
\text { and younger }\end{array}$} \\
\hline \multicolumn{2}{|c|}{$\begin{array}{l}\text { Multiple buildings providing community } \\
\text { resources }\end{array}$} & \multicolumn{2}{|c|}{$\begin{array}{l}\text { Relied on others and the surroundings to } \\
\text { survive }\end{array}$} \\
\hline \multicolumn{2}{|c|}{ Common space shared with multiple people } & \multicolumn{2}{|c|}{$\begin{array}{l}\text { Adjusted to multiple people in one room } \\
\text { sharing amenities }\end{array}$} \\
\hline \multicolumn{2}{|c|}{ Place for girls and boys to interact } & \multicolumn{2}{|c|}{$\begin{array}{l}\text { Learned to live with people of the opposite } \\
\text { sex in an informal way }\end{array}$} \\
\hline \multicolumn{2}{|c|}{ Place to potentially form new friendships } & \multicolumn{2}{|c|}{ Made new friends from different places } \\
\hline \multicolumn{2}{|c|}{ Shared memories created with social group } & \multicolumn{2}{|c|}{ Made new memories with roommates } \\
\hline \multicolumn{2}{|c|}{$\begin{array}{l}\text { Social groups where disagreements } \\
\text { occurred }\end{array}$} & \multicolumn{2}{|c|}{$\begin{array}{l}\text { Worked out the disagreements with } \\
\text { roommates and continued to live together }\end{array}$} \\
\hline \multicolumn{2}{|c|}{ Limited personal storage space } & \multicolumn{2}{|c|}{$\begin{array}{l}\text { Became more aware of necessities during } \\
\text { time away and reliant on few possessions } \\
\text { (or share with others) }\end{array}$} \\
\hline
\end{tabular}

The cabin is the social center for many camps, where previously unknown campers slowly get to know one another as they participate in a variety of group activities, rituals, and traditions. Over a relatively short period of a few days or weeks, this social setting provides campers with 
Camp and College Parallels

the opportunity to make new friends, experience and resolve conflict, and develop deep relationships. With these new friends, campers are less accountable for (or beholden to) their past, as they are now with primarily strangers. This freedom from the past allows campers to describe and define themselves differently - to be the type of person they want to be and not necessarily the person they typically are at home. Campers develop and rehearse new identities [a point also noted for camp staff (Johnson, Goldman, Garey, Britner, and Weaver, 2011)]. For example, campers who would typically be perceived as introverted and shy at home, in school, or around their neighborhood, can portray themselves as extroverted and outgoing at camp. They can become their ideal self and practice the new identity. As campers perceive the reactions of peers who are new to them, they can adjust their actions or words in ways that may be more difficult at home, because those peers know a person's history. Similarly, at college, being surrounded by new people gives students the opportunity to foster a new identity or to deepen perceived strengths. College students are initially strangers to each other and can present their ideal self to each other. The recognition that one can be liked by people who have no past connection reinforces identity development based on social feedback.

\section{Emotional Development Parallels}

Emotional development provides adolescents with self-esteem, conflict resolution skills, confidence, autonomy, identity, and a purpose in life (NRC, 2002). Table 4 parallels emotional elements of camp and college along with their resulting outcomes experienced by campers and students.

At camp, campers experience and adjust to separation anxiety and/or homesickness (see Thurber \& Sigman (1998) for a review of camp-related homesickness). Camp may be the first opportunity for a child to learn how to cope successfully with such separation (e.g., selfsoothing, talking about feelings to a peer or caring adult staff, getting involved in activities to take their mind off their worry) in a non-family environment. At camp, staff members mentor and guide campers in decision-making, challenges with friends, or homesickness. At college, students have academic advisors, faculty, and staff to help mentor and guide them in academic situations and resident advisors to address roommate and peer group challenges. Campers can develop an allegiance or affinity for that camp as they feel more emotionally connected. When the camper first arrives, they engage in the culture of that specific camp that fosters community: the camp songs, the traditions, the rituals, the symbols, and the camp terminology (Garst, Browne, \& Bialeschki., 2011). People who never attend the camp may not fully comprehend the culture. At college, students can develop an affinity to their respective college 
Camp and College Parallels

by being immersed in the culture. As a first semester college student, there is freshman orientation, the college t-shirt, late nights at the library, and the rituals that connect the person to the campus identity. Both campers and college students are put into an environment that test their emotions, and with those tests comes the opportunity for reflection, resilience, learning, and growth.

Table 4. Emotional Development Parallels between Camp and College

\begin{tabular}{|c|c|c|c|}
\hline Camp provides & College provides & $\begin{array}{l}\text { Camper } \\
\text { experiences }\end{array}$ & $\begin{array}{l}\text { First-year student } \\
\text { experiences }\end{array}$ \\
\hline $\begin{array}{l}\text { Doors and windows } \\
\text { without locks }\end{array}$ & $\begin{array}{l}\text { Times with open } \\
\text { doors in the hallway }\end{array}$ & $\begin{array}{l}\text { Felt safe without } \\
\text { locks }\end{array}$ & $\begin{array}{l}\text { Learned when to trust hall } \\
\text { mates and leave doors open }\end{array}$ \\
\hline $\begin{array}{l}\text { Counselors and } \\
\text { activity leaders as role } \\
\text { models }\end{array}$ & $\begin{array}{l}\text { Professors, RAs, } \\
\text { and staff as role } \\
\text { models }\end{array}$ & \multicolumn{2}{|c|}{$\begin{array}{l}\text { Listened to staff as they guided campers/students } \\
\text { through daily activities, nightly routines, friendships, } \\
\text { disagreements, etc. }\end{array}$} \\
\hline \multicolumn{2}{|l|}{ Social interaction spaces } & $\begin{array}{l}\text { Connection to camp } \\
\text { engendered through } \\
\text { traditions and rituals } \\
\text { (songs, food, games) }\end{array}$ & $\begin{array}{l}\text { Affinity with college } \\
\text { encouraged through athletic } \\
\text { events, school colors, } \\
\text { mascot, classes, and } \\
\text { different organizations/ } \\
\text { groups }\end{array}$ \\
\hline \multicolumn{2}{|c|}{ Anticipation of experiencing the unknown } & $\begin{array}{l}\text { Nervous about what } \\
\text { camp would be like }\end{array}$ & $\begin{array}{l}\text { Nervous about what college } \\
\text { would be like }\end{array}$ \\
\hline \multicolumn{2}{|l|}{ Opportunities for choice } & $\begin{array}{l}\text { Made choices with } \\
\text { little guidance (e.g. } \\
\text { daily hygiene rituals, } \\
\text { clothing, food, } \\
\text { activities) }\end{array}$ & $\begin{array}{l}\text { Made choices with little } \\
\text { guidance (e.g. daily hygiene } \\
\text { rituals, clothing, food, } \\
\text { activities) as well as choices } \\
\text { affecting future, morals, } \\
\text { safety }\end{array}$ \\
\hline \multicolumn{2}{|c|}{$\begin{array}{l}\text { Situations that push one outside of comfort } \\
\text { zone }\end{array}$} & \multicolumn{2}{|c|}{ Overcame fears by attempting new, unique activities } \\
\hline
\end{tabular}


Table 4. (continued)

\begin{tabular}{|c|c|c|c|}
\hline Camp provides & College provides & Camper experiences & $\begin{array}{l}\text { First-year student } \\
\text { experiences }\end{array}$ \\
\hline \multicolumn{2}{|c|}{ Need to share a bathroom } & \multicolumn{2}{|c|}{ Wrestled with personal modesty standards } \\
\hline \multicolumn{2}{|c|}{ Space to form new identity } & \multicolumn{2}{|c|}{ Experimented with different identities } \\
\hline \multicolumn{2}{|c|}{ New situations and circumstances } & \multicolumn{2}{|c|}{$\begin{array}{l}\text { Managed the ups and downs of emotions } \\
\text { caused by activities, friendships, and setting }\end{array}$} \\
\hline \multicolumn{2}{|c|}{ Strangers to interact with } & \multicolumn{2}{|l|}{ Trusted strangers } \\
\hline \multicolumn{2}{|c|}{ Self-reflection opportunities } & \multicolumn{2}{|c|}{$\begin{array}{l}\text { Gained humility by opportunity to attend camp } \\
\text { and college }\end{array}$} \\
\hline \multicolumn{2}{|c|}{ Potential to navigate separation anxiety } & \multicolumn{2}{|l|}{ Coped with homesickness } \\
\hline
\end{tabular}

\section{Intellectual Development Parallels}

Intellectual development is the ability to make good decisions, understand the essential skills to be successful, and think critically (NRC, 2002). Table 5 describes intellectual elements of camp that have parallels with college along with their resulting outcomes.

At camp, campers can make their own choices with minimal guidance. Novel activities not readily available during the school year stimulate campers' brains (e.g. memorizing lines for the play, delving deeper into a favorite new activity, or learning names of people/places/rituals). The process of trying a camp activity and deciding you like it offers self-analytical reflection. At college, students face choices with limited guidance, such as selecting a new course, major, or career path. Deciding what is appropriate to do during free-time is a daily choice for college students. Choices at camp about how to occupy oneself during quiet time and free time can serve as guidance for participation in extra-curricular activities. Camp and college are both organized around learning and individual choices that offer opportunities to master skills and interests. 
Camp and College Parallels

Table 5. Intellectual Development Parallels between Camp and College

\begin{tabular}{|c|c|c|c|}
\hline Camp provides & College provides & Camper experiences & $\begin{array}{l}\text { First-year student } \\
\text { experiences }\end{array}$ \\
\hline \multicolumn{2}{|c|}{ Opportunity to manage money } & $\begin{array}{l}\text { Managed money to buy } \\
\text { snacks or souvenirs in } \\
\text { the camp store }\end{array}$ & $\begin{array}{l}\text { Managed money for } \\
\text { personal products, } \\
\text { nights out with friends, } \\
\text { gas, etc. }\end{array}$ \\
\hline \multicolumn{2}{|c|}{ Communal responsibilities } & $\begin{array}{l}\text { Responsible for part of } \\
\text { group chores }\end{array}$ & $\begin{array}{l}\text { Learned to take } \\
\text { personal responsibility } \\
\text { for oneself and one's } \\
\text { belongings }\end{array}$ \\
\hline \multicolumn{2}{|c|}{ Different/novel activities not regularly available } & \multicolumn{2}{|c|}{ Different activities based on interests } \\
\hline \multicolumn{2}{|c|}{ Experiential education } & \multicolumn{2}{|l|}{ Learned by doing } \\
\hline \multicolumn{2}{|c|}{ Potentially scary situations } & \multicolumn{2}{|c|}{ Learned steps to take when scared or unsure } \\
\hline \multicolumn{2}{|c|}{ Responsibility for belongings } & \multicolumn{2}{|c|}{$\begin{array}{l}\text { Organized personal belongings to keep up with } \\
\text { them }\end{array}$} \\
\hline \multicolumn{2}{|c|}{ Interaction with different people } & \multicolumn{2}{|c|}{$\begin{array}{l}\text { Recognized similarities and differences between } \\
\text { oneself and others }\end{array}$} \\
\hline \multicolumn{2}{|c|}{ Leadership opportunities } & \multicolumn{2}{|c|}{ Learned how to lead icebreakers } \\
\hline \multicolumn{2}{|l|}{ Food choices } & \multicolumn{2}{|c|}{$\begin{array}{l}\text { Learned why a nutritional meal is important to } \\
\text { function properly }\end{array}$} \\
\hline
\end{tabular}

While camp and college elements were presented here separately and summarized in Tables 1 through 5, one must recognize that most experiences are not unidimensional but exist in combination. For instance, "shared bathrooms" is a socio-physical phenomenon. Making new friends was classified as a social-emotional experience that requires both intellectual skills and connection qualities influenced by physical spaces. The process of human development is complex and influenced by various dimensions in a child's ecology (i.e., self, family, community). Both camp and college mirror that complexity. College is a transition with multiple turning-points for adolescents. The first year or term of college can be an intimidating time if the student has never had a similar experience. As illustrated, the transition to camp as a child is a parallel experience to an older adolescent transitioning to college where college is an 
extended version of camp (Baskin, 2016a \& Baskin, 2016b). Once camp professionals better understand the parallel transition process, then proactive steps could be taken to make the camp-to-college connection visible.

\section{Implications for Youth Development Professionals}

Even though camps and colleges are structurally and experientially different, common dimensions exist among residential summer camps and colleges around the United States. Camp directors may take this conceptual idea and brainstorm elements that at first seem straightforward but are often not given the attention needed to clearly articulate the connections with developmental outcomes. Reflecting on and discussing these camp-to-college elements with staff may generate ways to intentionally modify camp experiences to prepare campers for their future college experiences or simply make the intellectual, social, physical, and emotional pillars (i.e., the desired outcomes of YDPs) more explicit as milestones for the campers. Camp directors may be able to capitalize on the awareness of the camp-to-college transition connection to market the value of the camp experience. Parents want their children to navigate life successfully, and camps ideally want to communicate how their camp experience could help with a successful transition to college. It can be difficult for parents to teach their children transition skills such as sharing a bathroom with others, coping with homesickness and separation, or trusting in others. There are naturally occurring non-academic features that occur in camp that provide experiences not readily available at home, and camp provides them in a supportive environment designed to encourage rapid adjustment.

\section{Implications for Higher-Education Professionals}

Student affairs professionals on college campuses can look to summer camps as a model for designing experiences to help students navigate the first-year transition. Most campuses have positions such as orientation advisors and resident advisors, who serve as a "counselor" for new students. Some universities partner with local camps to design non-traditional student orientation systems that capitalize on the natural environment or create small group teambuilding opportunities with activities that are similar to many traditional summer camps. Sports teams, social groups and student organizations may participate in group initiatives, some on camp properties, to connect new members and set the tone within the organization. These programs are designed to focus on the transition to college while using elements of the summer camp experience (e.g., the place, the activities, the social supports) as a model or to encourage 
Camp and College Parallels

the successful student integration to college life. Camps could capitalize on this link and partner with their local institution of higher education to help assist in the implementation of such programs and opportunities.

\section{Future Research}

The research community needs to further explore the connections between successful navigation of turning-points at camp with similar challenges in college. While this conceptual argument is supported by previously cited research and anecdotal reports, understanding how specific physical, social, emotional, and intellectual elements impact the developmental cycle of campers offers tangible recommendations to support youth development in both camp and college contexts. Conventional wisdom acknowledges that some young people credit their camp experiences with helping them successfully transition to college, but empirical research might lend a different lens to understand that impression. Evidence such as grades, peer groups, risk awareness attributes, drop-out and retention rates, graduation rates, income, family establishment, civic engagement is needed to document the successful transition of youth to adulthood. Tracking campers as they move to college as well as surveying first year college students about their preparatory experiences in light of their choices in the first few semesters would likely yield important information about the camp-college connection.

Partnering with developmental psychologists, social psychologists and organizational development colleagues could result in new tools to ask questions related to self-efficacy, identity, and resilience to determine direct linkages from the generic elements that make up the camp experience to the desired outcomes. Former campers are making these connections in their blog posts; social science needs to catch up with their insights.

Future research should examine between-camp variability with these experience domains to develop a better way to articulate the differences between types of camp programs and their impacts on specific desired outcomes. Not all camps aim to provide the same outcomes, just as each student that attends college will not achieve the same outcomes. These precise descriptions could begin the process of explaining the processes that lead to the outcomes already documented in research on camps. 


\section{The Camp-to-Campus Connection}

The popular press is filled with examples of campers who attribute their success in college to their camp experience. What they are expressing is that camp served as a turning-point in their lives in a series of transitions that changed the trajectory of their life. This article illustrates how the novelty of the camp-experience across physical, social, emotional, and intellectual domains focuses potential for multi-dimensional developmental growth uniquely different from other youth development settings and has multiple parallels to the college experience. In a sense, camp is an opportunity to learn and practice skills needed in the future. A successful camp experience helps youth realize they have the confidence to go away to college, consider study abroad, talk strategically and effectively with their roommate, and engage in clubs and extracurricular activities. Some former campers expressed that they can trace decisions about choice of college, identification of a major, and career choices back to their camp-experience. The camp experience gave them the opportunity for basic physical, social, emotional, and intellectual work that allowed them to feel confident about navigating the college campus, sharing the residence hall bathroom with multiple people, dealing with homesickness, and resolving conflict with their roommates. Campers realized that the fear and uncomfortable adjustments that many first-year students experience were no big deal, because they went to "college" for the first time when they were 10. And they loved it.

\section{Acknowledgment}

The authors wish to thank the reviewers and copy editors for improving this manuscript. This paper was unfunded other than routine salary support for faculty by Clemson University. The initial idea for this paper emerged from discussions of one of the authors and Jeremy Culpepper.

\section{References}

Baskin, L. (2016a, February, 23). Success in college and a personal letter, Part 1 [Blog post]. Retrieved from http://blog.campchampions.com/success-in-college-and-a-personal-letter-part-1

Baskin, L. (2016b, February, 23). Success in college and a personal letter, Part 2 [Blog post]. Retrieved from http://blog.campchampions.com/success-in-college-and-a-personal-letter-part-2

Bixler, R. D. \& James, J. J. (2016). Where the sidewalk ends: Pathways to nature-dependent leisure activities, In D. Kleiber \& F. McGuire (Eds.). Leisure and Human Development, 107-131. Urbana, IL: Sagamore Publishing. 
Journal of Youth Development | http://jyd.pitt.edu/ | Vol. 13 Issue 1-2 DOI 10.5195/jyd.2018.558

Camp and College Parallels

Brown, N. R., Hansen, T. G. B., Lee, P. J., Vanderveen, S. A., \& Conrad, F. G. (2012). Historically-defined autobiographical periods: Their origins and implications. In D. Berntsen \& D.C. Rubin (Eds.) Understanding autobiographical memory: Theories and approaches, (pp. 160-180). New York: Cambridge University Press.

Bourdeau, V. D., Galloway, R., Arnold, M., \& Nott, B. D. (2014). Impact of a middle school 4-H science camp on college aspirations of alumni. Journal of Extension, 52(1), n1.

Clausen, J. A. (1995). Gender, context, and turning-points. In P. Moen, G. Elder, \& K. Lüscher (Eds.), Examining lives in context, (pp. 365-389).Washington, DC: American Psychological Association.

Derksen, T. (2010). The influence of ecological theory in child and youth care: A review of the literature. International Journal of Child, Youth and Family Studies, 1(3/4), 326-339.

Enz, K. F., \& Talarico, J. M. (2015). Forks in the road: Memories of turning-points and transitions. Applied Cognitive Psychology, 30(2), 188-195.

Funnell, S. C., \& Rogers, P. J. (2011). Purposeful program theory: Effective use of theories of change and logic models (Vol. 31). John Wiley \& Sons.

Gambone, M. A., \& Connell, J. P. (2004). The community action framework for youth development. The prevention researcher, 11(2), 17-20.

Garst, B., Browne, L., \& Bialeschki, M. D. (2011). Youth development and the camp experience. In L. Allen and R. Barcelona (Eds.), New Directions for Youth Development [Special Issue on Recreation as a Developmental Experience], 130, 73-87.

Garst, B. A., Erceg, L., \& Walton, E. (2011). The healthy camp study impact report: Promoting health and wellness among youth and staff through a systematic surveillance process in day and resident camps. Retrieved from American Camp Association website:

https://www.acacamps.org/downloads/healthy-camp-study-impact-report

Garst, B. A. \& Gagnon, R. J. (2016). A structural model of camp director practices and outcomes: Does intention toward program outcomes matter? Journal of Park and Recreation Administration, $34(4), 51-65$.

Graber, J. A. \& Brooks-Gunn, J. (1996). Transitions and turning-points: Navigating the passage from childhood through adolescence. Developmental Psychology, 32, 768-776.

Henderson, K. A., Whitaker, L. S., Bialeschki, M. D., Scanlin, M. M., \& Thurber, C. (2007). Summer camp experiences: Parental perceptions of youth development outcomes. Journal of family issues, 28(8), 987-1007.

Johnson, S. K., Goldman, J. A., Garey, A. I., Britner, P. A., \& Weaver, S. E. (2011). Emerging adults' identity exploration: Illustrations from inside the "camp bubble". Journal of Adolescent Research, 26(2), 258-295.

Kagan, J. (1984). The nature of the child. New York, NY: Basic Books. 
Journal of Youth Development | http://jyd.pitt.edu/ | Vol. 13 Issue 1-2 DOI 10.5195/jyd.2018.558

Camp and College Parallels

Kaplan, R., Kaplan, S., \& Ryan, R. (1998). With people in mind: Design and management of everyday nature. Washington, DC: Island Press.

Kirk, R., \& Day, A. (2011). Increasing college access for youth aging out of foster care: Evaluation of a summer-camp program for foster youth transitioning from high school to college. Children and Youth Services Review, 33(7), 1173-1180.

National Research Council. (2002). Community programs to promote youth development. Washington, DC: National Academies Press.

Pickles, A., \& Rutter, M. (1991). Statistical and conceptual models of 'turning-points' in developmental processes. In D. Magnusson, L. R. Bergman, G. Rudinger, \& B. Torestad (Eds.), Problems and methods in longitudinal research: Stability and change (pp. 133-165). Cambridge, UK: Cambridge University Press.

Rutter, M. (1996). Transitions and turning-points in developmental psychopathology: As applied to the age span between childhood and mid-adulthood. International Journal of Behavioral Development, 19(3), 603-626.

Scheder, C. M. (2016). Perceptions of transitions into college through acquisition, transfer, and application of knowledge gained in youth programs. (Unpublished Dissertation). Edgewood College.

Schwartz, M. (2015, October 6). How summer-camp prepared me for college. Retrieved August 14, 2017. https://www.theodysseyonline.com/how-summer-camp-has-prepared-me-for-college

Sims, E. (2015, April 6). How summer-camp prepared me for college. Retrieved August 25, 2017 from https://www.theodysseyonline.com/how-summer-camp-prepared-me-for-college

Thurber, C. A., \& Sigman, M. D. (1998). Preliminary models of risk and protective factors for childhood homesickness: Review and empirical synthesis. Child Development, 69(4), 903-934. 